\title{
Turkish Secondary Education Students' Perceptions of Justice and Their Experiences of Unjustice
}

\author{
Sinem $\operatorname{Tarhan}^{1}$ \\ ${ }^{1}$ Department of Educational Sciences, Faculty of Education, Bartın University, Bartın, Turkey \\ Correspondence: Sinem TARHAN, Department of Educational Sciences, Faculty of Education, Bartın \\ University, Bartın, Turkey. E-mail: tarhansinem@gmail.com
}

Received: November 26, 2017

Accepted: December 19, 2017 Online Published: January 16, 2018

doi:10.5539/jel.v7n2p247

URL: http://doi.org/10.5539/jel.v7n2p247

\begin{abstract}
The purpose of this study was to identify how secondary education students define the concept of justice, based on which criteria they define their experiences as just/unjust, what they see as the source of injustice, how they feel and how they behave when they face injustice.

This study was designed as a qualitative research study. Open-ended questions were asked to the students and they were asked to give detailed answers. Descriptive analysis was used in analysing the collected data. The study group consisted of students studying at 9th, 10th, 11th and 12th grades in different types of high schools (Anatolian High School, Vocational School for Girls, Science High School). A total number of 268 high school students participated in the study. We used convenience sampling to choose the study group.

The results of the study indicated that students defined the concept of justice with the "equality, equity non-discrimination, respect, rights and freedoms, conscience, rights, deciding the right, being fair and needs" concepts. The students see grades, school rules and non-communication they experience with their teachers and principals as unjust, so they point the school principals as the source of injustice. Besides, the students indicated that they had negative feelings when they experienced something that is not just but preferred to stay silent.
\end{abstract}

Keywords: school justice, justice perception, justice experiences, equity

\section{Introduction}

In one of the best known definitions, education is the process of purposefully forming desirable changes in one's behaviours through their own experiences (Ertürk, 1994). These desired changes involve not only academic knowledge but also attitudes, behaviours, skills, moral values and philosophy of life. One of the major values that individuals should be equipped with throughout the process of education, which starts in the family and continues at school and in the social system, is justice. The behaviour that shows justice is "being fair." Kayaoglu (1986) makes a direct connecting between the concepts of justice and being moral, and indicates that if someone is fair, then they are moral.

Aristoteles described the concept of justice as the most perfect virtue containing all values and describes it as a conduct in agreement with the law (Topakkaya, 2009). Justice is defined as ensuring the rights given by laws to be used by everyone, giving everyone their right and what they are entitled to have, trueness, compliance with rights and laws (TDK-Turkish Language Society-2017). According to Hobbes, an English philosopher, the essential condition for having justice in a society is ensuring safety and order. Without safety, the major values like life, freedom, possession or equality cannot come true (cited in Guriz., 1994).

Justice has legal, social and religious dimensions and the source of justice as well as how to ensure justice have been an issue of philosophical discussions. Justice has been included in the teachings of religious figures and has been shown as the ground for leaders and statesmen to gain power (Karaeminoğulları, 2006). Respecting the rights of one another, being tolerant to differences in language, religion, belief and political view, behaving justly and rightly are only possible first by one's own conscience and then by the presence of the existence of justice in a social system. The justice in social system is one of the important values in ensuring social peace and tranquillity.

In the preamble of the 1982 Constitution of the Republic of Turkey, it is stated that "it is the birth right of every Turkish citizen to lead an honourable life and develop his material and spiritual resources under the aegis of 
national culture, civilization and the rule of law, through the exercise of the fundamental rights and freedoms set forth in this Constitution, in conformity with the requirements of equality and social justice." And similarly, in the $1^{\text {st }}$ article of the Universal Declaration of Human Rights (1948) it is given that "All human beings are born free and equal in dignity and rights. They are endowed with reason and conscience and should act towards one another in a spirit of brotherhood."

How and under the impact of which conditions the concept of justice develops in humans are examined through different theoretical structures. According to Havinghurst, learning the to know right from wrong until the age of 6 , developing conscience, morality and values system and developing personal independence until the age of 12 are developmental tasks (Yesilyaprak, 2012; Erkan, 2008). Freud claims that at around 5 years old, when the Oedipus complex is resolved and with the development of superego, the third part of personality, a child learns the rules of his/her parents first and then the rules of the society. In accordance with these rules and values, superego considers behaviours as good-bad, right-wrong and it reflects the moral rules of individuals (Corey, 2005; Oztürk, 2008). Piaget explains moral development in relation to cognitive development and he emphasizes the significance of abstract thinking in moral development and indicates the necessity of autonomous thinking and reasoning (Cam, Cavdar, Seydoogullari, \& Cok, 2012). Kohlberg (1971) claims that justice, equality, respect to human and the principle supporting human being is precious lie at the bottom of the moral judgements of an individual (cited in. Bayer, 2008).

In social theory, Bandura states that starting with the family, a child imitates, observes and takes the people around him/her as a model and therefore, it is important that child sees good models for moral development (Miller, 2008). The culture one lives in effects moral development; behaviours accepted by the society are supported and the ones that are not accepted are punished (Akbaba, 2008). Gesell claims that moral awareness develops as of 15 years old; Debesse, on the other hand, claims that the concept of value starts developing as of 15 years old and starts to have a social content (Onur, 1979). Havinghurst indicates that dealing with social problems, creating self-moral judgements and a life philosophy, being ready to take social responsibility and performing the social tasks are among the developmental tasks of adolescence (Erkan, 2008).

The perception of justice is one of the important issues for educational institutions (Erkan, 2013). All the practices of educational institutions, which aim to educate happy, peaceful, productive and responsible citizens, have to be just. Principals and teachers are both the symbols of authority and educational models. Glick (1985) claims that the environment one lives in is a determining factor of the behaviours (cited in. Ripski \& Gregory, 2009). Accordingly, the practices of principals to the school personnel and students, and the words and behaviours of teachers to the students in a class may lead either to the development of the awareness of justice or the ignorance of the concept of justice. Fair practices students see in the school strengthen the perception of a world in which good and right wins; whilst unfair practices could cause students to be hopeless and lead them believe in a world that is not fair.

Aristoteles claimed that the concept of justice should be considered from two perspectives: distributive and corrective justice. Distributive justice is getting one's own share based on the skills of the individual and his/her status in the society in the distribution of honours and property. The equality in distributive justice is not absolute but relative. As for Aristoteles, corrective justice is equal treatment of both sides in a legal relationship (Güriz, 1994). The use of the concept of justice in organizations was first made by Greenberg. Greenberg classified organizational justice as reactive, proactive and process-content dimension. In reactive dimension, the focus in on the reactions (content) given to the distribution of awards or the ways of determining the awards (process). In proactive dimension, on the other hand, the focus is on the distribution of awards to the individuals (content) or the process of distribution of awards (cited in. Steiner, Trahan, Haptonstahl, \& Fointiat, 2006). Paulsel \& Chory-Assad (2005) and Chory (2007), Paulsel \& Chory-Assad (2005) applied distributive, procedural and interactional justice, which are the three dimensions of organizational justice, to education. Within the context of education, justice stands for the awareness on the process or the results (Chory-Assad \& Paulsel, 2004). Distributive justice stands for the equality in distributing income, awards and opportunities; whilst procedural justice stands for the justice of the decisions of principals not changing according to the individual, time and environment; and interactional justice stands for carrying out interpersonal relationships with all employees within the framework of equality (Colquitt, Greenberg, \& Zapata-Phelan, 2005). While distributive justice could be related to needs, equality, personal interest, commitment to responsibilities, status, effort and/or qualification (Deutsch, 1985) procedural justice represents consistency in practices, valid ethical standards, the degree of prejudices, rightness and applying all of the given in the same way towards all individuals (Leventhal,1980; cited in. Chory-Assad \& Paulsel, 2004). Interactional justice, on the other hand, is about how respectful, kind and open the communication between the teacher and students is (Chory-Assad \& Paulsel, 2004). According to 
Reyna \& Weiner (2001), punishments and interventions in class are used not only as a behavioural tool but also to create and sustain class norms, communicate expectations and ensure justice.

When the literature is reviewed, it is seen that various studies on justice are being carried in Turkey. Some of these studies are conceptual studies on the development of justice or morality among children and adolescents (Cam, Cavdar, Seydoogullari, \& Cok, 2012; Gunduz, 2000), ethical judgement levels of teenagers (Bayer, 2008), belief in just world among teenagers (Gokler, Danisman, \& Berberoglu, 2016), justice perception among university students in the classroom (Kepekcioglu, 2015). In addition, it is also seen that some of the studies on justice are carried out about organizational justice and teachers. Examples of these studies are teachers' understanding of organizational justice (Polat \& Ceep, 2008; Comert, Dermirtas, Ustuner, \& Ozer, 2008), the relationship between the favoritist attitudes and behaviours of the school principals and teachers' perception of organizational justice (Polat \& Kazak, 2014), and a conceptual analysis in educational organizations (Toremen \& Tan, 2014). In addition, the relationships between organizational climate, organizational commitment and justice are examined in different institutions. However, there are no studies found directly examining the thoughts of secondary school students on justice in the literature. Therefore, this study was designed to examine how secondary school students define the concept of justice, based on which criteria they define their experiences as just/unjust, what they see as the source of injustice, how they feel and how they behave when they face injustice. Accordingly, the study was guided by the following research questions:

1) How do the students define the concept of "justice"?

2) What are the criteria leading the students comment on a situation as fair/unfair?

3) What do the students see as the source of injustice?

4) How do the students feel when they experience unfair situation?

5) How do the students react when they experience unfair situation?

It is believed that the results of the study will contribute to how the concept of justice is defined and perceived and to solving the problems in school management and school climate at secondary schools.

\section{Method}

\subsection{Research Design}

This study is a qualitative study. Qualitative studies include techniques that reach concepts related to defining, solving, interpreting and comprehending. Qualitative research is related to how reality is constructed and what meaning they attribute to their experiences and lives (Merriam, 2013, p. 24). The current study was an exploratory and descriptive qualitative study. Qualitative methods were used to explore people's knowledge, attitudes, and behaviours relating to justice and injustice in depth.

\subsection{Study Group}

Convenience sampling method was used in choosing the study group. Convenience sampling is sampling method from a voluntary population chosen because of their convenience accessibility (Erkuş, 2005). The study group of this study was 9th, 10th, 11th and 12th grade students from different high schools (Anatolian High School, Vocational School for Girls and Science High School) in a city in Black Sea Region in Turkey during 2017-2018 academic year. A total number of 268 high school students participated in the study. Of all the participants, 198 were female (74\%) and 70 were male $(26 \%)$. The criteria to participate in the study were being a high school student and being voluntary.

\subsection{Data Collection Techniques}

Open-ended survey technique was used in order to identify how high school students define the concept of justice, based on which criteria they define their experiences as just/unjust, what they see as the source of injustice, how they feel and how they behave when they face injustice. In this scope, open-ended questions were asked and students were asked to give detailed answers to these questions. While creating the questions for the survey, an in-depth review of the studies on justice was made, literature was reviewed and opinions of an expert in psychological counselling and guidance working on the concept of "justice" were taken. To test the understandability of the questions, a short interview was made with a group of secondary school students and the questions were finalized.

The survey was administered by the researcher in the classroom and the privacy of the data were ensured by the researcher. The results of the observations of the researcher were transferred to unconstructed observation records. 


\subsection{Analysis of Data}

Descriptive analysis method was used in analysing the collected data. The objective of descriptive analysis is to present the findings in an organized and interpreted way for the reader (Yıldırım \& Şimşek, 2011, p. 187). Open-ended questions used in the study were considered as the framework and students' answers were organized around these frameworks. Direct quotations were given and interpreted while presenting the findings.

To ensure the reliability of the study, debriefing was made after the qualitative data were coded. As for Lincoln \& Guba (1985), experts who take part in debriefing are people who know the topic studied, who could provide support and who can manage the prejudices and assumptions of the researcher. Experts who examine ask researcher questions about the method and comments and thus, strengthen for the next step (cited in. Erkan, 2013). In the current study, a professor in the department of Psychological Counselling and Guidance and an associate professor in Social Studies, both of whom work on justice, were asked to look into and evaluate the data. After their examinations and analysis, they were in consensus and thus, coding was completed. Students were coded as F1, F2 and M1 and M2 according to their sex; and their opinions were given under these codes. In addition, unconstructed observation records made by the researcher during the administering of the questions were utilized.

\section{Findings}

When the high school students' answers to the question "How do you define justice?" are examined, it is found that the concept of justice is defined using the concepts of equality, equity, indiscrimination, respect, knowing their rights, freedom, conscience and basic needs.

Majority of the students considered justice equal to equality and defined the concept accordingly. Some examples from the answers of the students are given below:

- Justice is the equal share of rights, everyone's having equal rights and being judged equally before laws. (F255)

- Justice is the equal and consistent behaviour in every circumstance. (M12)

- It is the equality of everyone, approaching people under equal and same circumstances with same behaviour and care. (F27)

Some of the students, on the other hand, claim that justice and equality are different concepts and they shouldn't be used interchangeably. It is seen that students mention equity rather than equality in justice. Some examples from the answers of the students are given below:

- It is the thing happening not by being equal but by being fair. (F2)

- Justice is not equality. What is needed should be distributed as much as the need. (M52)

Students see justice as not making discrimination; and they defined justice as not discriminating people based on their language, religion, race, social and financial status and particularly based on their sex. Here, the importance of having equal rights for everyone is emphasized and it is seen that students especially mention sex indiscrimination. Some examples from the answers of the students are given below:

- It is behaving equally to everyone without considering religion, nationality or sex. (M200)

- It is paying regard to rights and remedies, distinguishing who is right and who is not. It is about indiscrimination. (F268)

- $\quad$ Justice is approaching people without classifying or discriminate them with leaving their identity aside. It is being able to look at an event objectively, not subjectively. (F88)

Respect towards each other is also included in the definition of the concept of justice. One of the student's answer is given below:

\section{- It is the respect between people. (F64)}

An individual's awareness of his own rights and protecting these rights freely are considered equal to justice. When justice is defined as a right, justice is getting what you deserve, living how you deserve, and equally getting the return for the good and bad things you do. It is seen that students emphasize equity while defining justice as a right. Moreover, being objective, not terminating with extreme prejudice, being able to recognize right and wrong, stating the right one and being fair are among the definitions of justice. Some examples from the answers of the students are given below:

- I think, justice is one's or a country's living without encroaching others' rights with and freedoms. (M206) 
- Justice underlies equality, freedom and tranquility, and it is being able to protect human rights and freedoms without spending too much effort. (M19)

- $\quad$ Justice is a way of life in which everyone lives as they deserve equally and has what they deserve (F23)

- Justice is the situation of separating right and wrong from each other. If there is no justice in a situation, there emerges chaos. It is going towards injustice. (F241)

Conscience which is self-evaluation and self-judgement of an individual, also stands out as an important factor in justice. Some examples from the answers of the students are stated below:

- Justice is the state of one's deciding to be human at first, then the state of ultimate relaxation when the one puts his head to the pillow. (M5)

- $\quad$ The definition of justice is impossible. However, if it can be defined, the most suitable definition will be conscience. If a person has conscience, he is fair. (M50)

Justice is defined as a basic need at the same time. It is a basic, necessary and primary need for life to protect rights.

- In a place without justice, the life bounds are weakening. Because misbehaviours are covered up and humanity dies. In my opinion justice is the base for life. (F220)

- Justice is an important concept that stands for protecting equal rights of people and for defending the rights when needed. Injustice decreases the quality of life. (F41)

Some of the students stated that they do not believe in the concept of justice because they are not living in a fair environment, so they define the concept of justice as empty, dream and hypothesis. The quotations from the sentences of the students are presented below:

- $\quad$ Justice is nothing more than a word with seven letters. There is not even a single letter of justice. I wish I could write longer but this is how much I can talk on such an empty word. (M232)

- $\quad$ Most of the places are now very far away from the word of justice. (M225)

- Justice is a fact changing up to how we define it. If it is thought according to my definition, justice is just a hypothesis, even a dream. Not even one situation in this world is fai.r (F22)

Another research question was: "Have you ever experienced or be a witness to any kind of unfair situation in this academic year at this school? Explain." Most of the students stated that they experienced unfair situations at school, while others stated they witnessed them. The situations students presented as unfair are classified as clothes, grades, favouring (one's superiority over another), school/education equipment, lack of communication with their teachers and school rules. Some example sentences of the students about unfair situations they face on the issue of clothing are given below:

- $\quad$ Our school has many rules. One of them is coming school in school uniforms. One person in class comes to school in plain clothes every day. The school management checks clothes almost every day and they take that person's number to send him to the principal. After a few minutes, that person takes the school uniform from his bag and puts them on. Then he goes to the principal's room and gets his number deleted. This school has certain rules. Everyone must obey them. If this person does not obey the rules, he must serve the sentence. (M207)

- $\quad$ There were controls of whether our school uniform is suitable or does someone comes to school in plain clothes? I am referred to disciplinary because of this reason. What makes the situation unfair is that some friends' names taken for many times, but nothing happen to them. My name is taken for once, and I am referred to disciplinary. (M237)

- $\quad$ Our school management make us take off our hats, rags, etc. Normally, there is no such point in the rules of school. It is only written that one cannot put on such accessories with any kind of political content. We talk on this with one of our managers and he still tells us that we cannot literally wear them. (F263)

Students stated that they face unfair situations in terms of grades as well. They stated that they saw or recognized that their teachers give low grades to the students they do not like or they cannot get on well with. One of the students' answer is presented below:

- $\quad$ The mathematics teacher who is new at the school asks the students he loves whether they understand the topic or not and the teacher solves the problems with them one-to-one and tells them every detail. However, he does not tell the ones he does not like or even he asks if they understand or not. Besides, he gives higher grades to the ones he likes to make them pass the class yet to the others he does not even give one extra grade. I see this 
event with my own eyes. I and my friend solve the question in the same way in an exam, the teacher gives my friend 10 grades and 5 grades for me. (M245)

If a student is not punished for a wrong doing is considered as favouring by some students. The students participating in the research indicated that they witnessed some students are treated in a special way due to the occupation of their fathers. There are some examples from the student statements on this topic below:

- $\quad$ One of my girlfriends is harassed in line at the cafeteria and this event is tried to be covered up and forgotten. The father of the counter student is an army officer so the boy is found innocent and no official act is made. (F266)

- $\quad$ One of our friends sees some other students from the school drinking alcohol while he hangs around the school during the lunch break. He presents this situation to the school management. But it is said to him that he is referred to disciplinary if he tells what he sees to anyone. So he takes his complaint back. After a while, it is understood that those guys' fathers are police officers. (M251)

At school, sometimes there are arguments and verbal or physical fights. The reasons of such fights are generally teasing or provocation. The parties of the fight see this situation as unfair since the teachers' not being objective. One student's answer is given below:

- I Ifight with one of the girls at school. I accept I am not right but there is two-sided interaction. She swears and provokes me, I use physical power. The school management does not give any sentence to her but me. (F264)

The condition of school equipment and furniture are also shown as example to unfair situations. The fact that some schools are given tablets by the Ministry of National Education of Turkey but others are not, old school equipment are recognized as unfair. The quotations from the sentences of the students are stated below:

- $\quad$ Every school gets tablets yet our school does not as if we are alienated. (F181)

Our desks are old. The desks at other schools are not like these. This is unfair. (F204)

Students see the inconsistencies in the punishments of forbidden situations because the discipline rules are not implemented properly as unfair. Besides, they believe that subjective attitudes of some of the teachers while looking into some situations are unfair. Some student statements are given below:

- I witness that our teacher listens to the guilty side without listening the innocent ones and so he commits injustice. (F213)

- $\quad$ The necessary attitude is not used for the ones smoking (for example they are sentenced with the lightest punishments) and for the ones coming school in plain clothes creates an unfair situation for the ones wearing school uniforms. (M216)

In the research, the quotations taken from the high school students' answers to the question "Why do you consider this situation unfair? What do you think makes the situation unfair?" When the answers of the students are examined, it is found that the criteria for them to state this situation as unfair are discrimination, favouring, sanctions, ignorance/insensivity and non-communication. The situation students see as discrimination and unfair is that teachers give higher grades to the hardworking students they love and that they do not even take in attention the effort others make. According to the students, some students' having priority due to their fathers' jobs without getting punishment for their misbehaviours and the school rules' not being practiced enough or the awareness of the justice concept is weak result in unfair situations. Some examples from the answers of the students are stated below:

- There is injustice in grading. The one makes the situation unfair is the teacher. Due to making discrimination by loving that girl more. (F189)

- $\quad$ The fact that the counter side's not getting punishment even if they are guilty and accepted innocent due to their fathers' job. (F266)

- $\quad$ The factor making this situation unfair is that the sanctions are not enough or equal in this situation. (M229)

- $\quad$ Because the ones at school do not know what is justice. (F137)

- I think this situation is unfair because you should give a chance to present oneself in order to understand whether he is just or unjust. You cannot ensure justice by imagining it in your mind. (M253) 
In the research, the students are asked "In your opinion, what is the source of the injustice and why did it happen?" and it is found that students see the school principal as the primary source of injustice, and the teachers as the secondary source. The examples of quotations from the sentences of the students are given below:

- $\quad$ The source of injustice is the school management because there is not enough discipline. (F228)

- $\quad$ The source of this injustice is the principal's irresponsibility and lack of interest in school issues. (F243)

- $\quad$ The source of this injustice is the teachers, their discrimination among students or their rejection to sending a beloved student to disciplinary. Such reasons and teachers' good will start this injustice. (M250)

- $\quad$ The fact that teachers' blaming a student without listening is injustice. I think, teachers and students cannot develop empathy so injustice emerges. (F177)

- In my opinion, the source is the prejudices of my teacher. Because he is stuck between the walls he builds himself. (F253)

- Insecurity, greed, anger, trying not to understand someone. If some teachers start really trying to understand us, there will be no injustice left. (F129)

- $\quad$ Teacher's commenting on me without knowing the reality. (F165)

- $\quad$ The silly rules teachers create in their minds. (F263)

Students show the source of all unfair practices as the principal's lack of practicing the school rules, lack of interest in school and lack of discipline at school. They state the source of the unfair practices as teachers' discrimination among students (loved or not loved ones), their acting with prejudice, their not being able to develop empathy with the students and the difference in opinions between teacher and student.

It is pointed as the source of injustice due to favouring that the jobs of some students' fathers, knowing their families, being a senior student, being a successful and loved student by teachers, giving importance to economic status, and not acting equally to the students. The examples of quotations from the students' answers are given below:

- Favouring. Because of their families are well-known. Because the student is comfortable at school just because of his/her family. (F254)

- The students' fathers' economical favours for parent-teacher association, their being well-known people or the friends of some teachers. (M37)

- $\quad$ The reason, from my point of view, is their not having punishment but the one making the complaint. What makes the situation unfair is the fathers' job of the students are complained. (M258)

- Because the things done by the other side are ignored. What makes the situation unfair is being subjective. (F264)

- $\quad$ The source of this situation is that the 12th classes are not care about such things due to their preparation for the exam. (F22)

- $\quad$ The source is their looking down on our class. (F131)

- $\quad$ Seeing a student superior to the others. (F190)

The sources of unfair situations are indicated as disrespectful and humiliating behaviours among students, superiority feeling of a class towards other classes, a student's large group of friends and thus, considering himself/herself right and superior with this large group of friends, lack of classroom teachers' interest and students' ignorance of the school rules.

Being extremely rule-based or not doing one's job properly and covering unfair cases are seen as reasons for unfair practices. For instance, focusing on clothing in the school rather than important cases and the lack of authority, discipline and democracy are considered as the reason for unfairness. In addition, teachers' subjective attitude and lack of understanding, and their prejudiced attitude and discriminating behaviours are seen as other reasons of unfairness.

- $\quad$ People's doing their jobs improperly creates this situation. (M252)

- $\quad$ The source is people's being rule-based. (M218)

- $\quad$ The source of injustice is lack of democracy. No one asks us what our opinion is. (F235)

- $\quad$ The conscience of teachers is the source of this. (F268) 
In the research, high school students are asked "How did you feel facing this injustice? Why?" Students stated that they had negative feelings when they experienced unfairness. Some of these feelings are: anger, sadness, madness, nerve, helplessness, weakness, anxiety, anxiety for future, doubting oneself, feeling guilty, restricted, looked-down, loser, unequal, discriminated, uncomfortable, feeling that justice does not exist, shame, hatred, nothingness, disappointment, shock, strangeness, insignificance, grudge, under pressure, struggling for nothing, ignorance, alienation, disaffection, unwilling to go to school, resentment. The examples of quotations taken from the answers of the students are shown below:

- I I get angry at the one's coming school without uniforms because I go in school uniforms. (M229)

- I Ifeel madness and inequality under this injustice because this is unfair. (F233)

- I get angry because the effort made is ignored like that. (M208)

- Ifeel like I am nothing. (M253)

- Ifeel like a diamond in trash and angry. (F128)

- Ifeel under pressure at school because I cannot explain myself. (F98)

- I feel bad. When there is an injustice, my reliance on school disciplinary is decreased. Because if such situations occur again, there will be injustice again. (M258)

- Ifeel offended and insulted. (F115)

- $\quad$ Like a slave, a sheep to be sacrificed. (F174)

- I get very angry at this unfair situation. My school success grade decreases 20 points for nothing, and I get warning. I get angry at most the teacher's answer in disciplinary "You have no luck, it is your turn, nothing to do." (M237)

Students witnessing injustice, on the other hand, indicated that in addition to having such feelings as sadness and anger, they empathized with the people. The examples of the quotations from the answers of the students are presented below:

- I get very sad and I mind as if I experience the same thing. I get very angry at the counter side. (F266)

- I get sad for my friend due to this unfair, I get anxious about his family. I may be in my friend's shoes, too. (F214)

- I develop empathy, I put myself in the other teacher's situation. It is an unequal situation. (F255)

Some of the students experiencing injustice indicated that they expected that injustice because they did not trust the people and the environment they live in and therefore, they felt nothing. The example sentence is as given below:

- In fact, I feel nothing, it is definitely the result I am waiting for. Because there is not any people who have potential to make me feel disappointed. (F264)

In the research, students were asked "How do you react this injustice? Why?". Some of the students indicated that they complained and tried to claim their rightness or by collecting evidence to prove their innocence. There are some students who try to compensate injustice through developing empathy as well. The examples from the answers of the students are presented below:

- My friend makes a complaint with writing a petition. (F209)

- I hear the guy is talking about this issue everywhere, and I record his speech to give disciplinary as evidence. (M223)

- We organize a surprise for our history teacher with buying a present because there is injustice for him before. (F255)

- We put on plain clothes as protest. (F137)

- I give my teacher some information and make a complaint. (K148)

- I have nothing to do then but I get mad and I tell it to my team friend because I only want to share it. (M208)

Most of the students did not react when they experienced an unfair situation. The reasons of being silent are belief that the effort they show will be in vain against the authority, the feeling of desperation arising as a result 
of the idea that "I cannot do or change anything" and the fear of punishment. The examples of quotations from the answers of students are stated below:

- I do not react because I think my reaction will worth nothing under the principal who says the last word and approves everything. (M207)

- I do not react. The reason is every time the teachers show themselves objective yet they always achieve to be seen right at the end. Even if we react, nothing will change because they pull the strings. (M250)

- $\quad$ They do not give us a chance to react or even allow us to speak, they directly give my hand the warning paper. (M237)

- I cannot react because I get punishment if I do. (M249)

- I cannot react because I cannot see anyone supporting me. Moreover, I think the teacher may oppress me with low grades. (M236)

\section{Results, Discussions and Suggestions}

The purpose of this study was to identify how high school students define the concept of justice, based on which criteria they define their experiences as just/unjust, what they see as the source of injustice, how they feel and how they behave when they face injustice.

The results of the study indicated that students defined the concept of justice with the concepts of "equality, equity, indiscrimination, respect, rights and freedoms, conscience, rights, deciding the right, being fair and need". Some students considered equality same as justice. This finding is complies with the literature. It is indicated that there is a close relationship between justice and equality and most of the time, the struggle made for justice aims to eliminate inequalities (Güriz, 1994). Accepting everyone equal before the law without distinction as to language, race, color, sex, etc. and protecting their rights and freedoms are considered as the indicators of justice in national and international laws (Constitution of the Republic of Turkey, 1982; Universal Declaration of Human Rights, 1948). Similar to what students defined, in the literature human is considered worthy of respect as a human being and respect is considered as justice (Güriz, 1994). Erdoğan (2008) indicates that freedom and equality are the basic principles of justice. In addition, freedom is a requirement of a fair society; and there is a close relationship between treating people equally and accepting the rights of the people and respecting them. Kuçuradi (2011) indicates that protecting human rights is meaningful for humans and that those who protect those rights are ethical people in their behaviors.

On the other hand, some students in the study indicated that equality did not have the same meaning with justice, and that it meant everyone to have what they deserve. In other words, they defined justice as equity. This definition of the students reminds Roman Jurist Ulpian's definition of justice. Ulpian defined justice as "a constant and perpetual will to give each and everyone their due." (Güriz, 1994). This is supported with the perception of believing in a just world. According to Lerner's "Just World Theory" people believe that they deserve what they live and that they get what they deserve. Accordingly, they preserve the idea that the world is a just place and they keep seeing the environment they live in as an organized and safe place (Gökler Danışman \& Berberoğlu, 2016).

Some of the students defined justice as empty product of dreams and they claim there exists no justice. The students in study group are adolescents. They are questioning life, past, future, the rules taught to them until present day, beliefs; they are interested in social issues and work on developing a life philosophy. It is possible to say that the things they experience or witness effect their point of view of justice and their belief in justice. Erkan \& Walker (2016) emphasize that the justice perception is not a permanent structure but rather it is highly fragile and even a single case could completely change such a positive image.

Majority of the students indicated that they had unfair experiences at school. The events that students define as unfair can be divided into three parts: distributive justice (grades, school/education equipment), procedural justice (clothing, school rules), and interactional justice (non-communication, favoring). The problems students experience in distributive justice range from not having the marks they deserve in a certain course to the practices and projects of the Ministry of National Education. Examples of unfair cases are stated as teachers' giving higher marks to those students they like or consider hardworking and not taking the efforts of other students into consideration. Old equipment in the schools and the tablets that the Ministry of National Education gave to some schools and not to others within the scope of a campaign creates a higher feeling of injustice. Such practices indicate that students do not get equal share from awards. 
Examples of problems in procedural justice are indicated as the implementation of school rules by the school administration and the teachers in a different way depending on time and people. Students mostly complain about clothing and the implementation of school rules. Although the clothing in the schools in Turkey is free, there are some restrictions in schools based on the schools' and the school-parent associations' decisions. Therefore, the fact that those students who come to school with clothes other than what school allows are not punished and those who wear accessories, bandanas and piercing etc. are always criticized attract attention. Students think that since clothing is free in the school, such accessories should be allowed too. Therefore, they consider interventions to accessories as unfair.

Examples of problems in interactional justice are the problems arising as a result of the lack of healthy communication between students and the teachers and the administration. Other factors considered as unfair are listed as not taking student's opinion when something happens, being prejudiced and assessing the student outside his/her academic achievement when giving marks. Students believe that some students are positively discriminated due to their father's occupation and not punished for their misbehaviours. In addition to that, not implementing the school rules effectively or low awareness on the concept of justice cause to unfair practices.

In the determination of students for defining a situation as fair-unfair, there is a role of their experiences. De Jong \& Schalk (2010) claim that the understanding of the concept of justice reflects the past and current experiences. It was found that when students assess something they experience as fair/unfair, they compare it with what their friends experience and that they consider it unfair when they are subject to a different treatment when they experience similar things. In other words, students consider those cases as unfair when they are not treated in an equal and equitable way. Which concept is emphasized in the perception of justice depends on the culture. In the literature, there are studies looking into justice perception of the adolescents in different cultures. Steiner, Trahan, Haptonstahl \& Fointiat, (2006) worked with American and French students and they found that American students tend to behave equitable whilst French students tend to behave equal. In his study on Muslim university students in Canada, Erkan (2013) indicates that students attach importance to equity in justice.

Nesbit \& Burton (2006) indicate that if students have concerns about the distribution of justice, they will be less satisfied with the results of assessment. Another example of that is free clothing implementation. According to Erkan (2003) although the perceptions of the parents, teachers and principals at the school on wearing uniforms at school are positive, deciding whether to support uniforms or free clothing at school is not an easy decision to make because free clothing implementation created differences in the application of rules and therefore, creates procedural injustice from students' point of view.

The main criteria for students to assess an experience as unfair are favouring someone in that case or discriminating someone, not applying the rules or punishments equally for everyone, being indifferent about justice and not communicating in a healthy manner. Therefore, behaving a student in a different way for a reason (favouring or excluding him/her) results in discrimination, and discrimination results in favouring. When the principals do not implement the rules in a consistent way, stay insensitive against injustice and do not communicate in a healthy manner when looking into a case cause to injustice. Discrimination which is closely related to justice (Harris, Lievens \& Van Hoye, 2004) depends on whether an individual sees the case as fair or not. Individuals first evaluate the justice of the procedure and then, compare the allocations that they were given with others. If they decide a certain act is unfair, they define it as discriminative (Houston \& Bettencourt, 1999; cited in. Erkan \& Walker, 2006). In the current study, it is found that discrimination is seen as the ground for other criteria causing to injustice.

When the students were asked the source of injustice they experience, mainly they indicated school principals. Besides, such things as thinking themselves as superior due to being successful or studying in an upper grade etc., teachers' lack of interest or ignorance, teachers' over prescriptivism, favouring and discriminative behaviours, lack of communication and being remorselessness were indicated as the source of injustice. It is believed that it is the attitude of the school administrator that lies on the ground of other reasons indicated as the source of injustice apart from the school principal. Because to what extent the written and non-written rules will be applied in the school and what will be considered when applying these rules are related to the meaning and significance attached to these rules. While procedural justice focuses on the justice of the rules and procedures used in decision making (Wendorf \& Alexander, 2005), distributive justice includes the appropriateness of the results of conflict resolution (Erkan, 2013). Interactional justice, which is the humanitarian side of the justice perception, is an essential aspect of justice in educational institutions (Schimdt, 2001). As for Şahin Firat (2010), the indicators of school culture are interactions arising from the communication of teacher, principal, student and staff. The most important element in this interaction is the school principal. According to Pehlivan (1998), first of all, this importance is because principals are the most authorized people in an institution which aim to equip people with 
the right behaviours and secondly, because they are authority figures for students and the people working there. Therefore, it can be said that if principals apply meaningful and acceptable rules for everyone, if they consider equality and equity in all their award and punishment practices and if they serve as role models in healthy communication for all the individuals at school, then unfair practices will be reduced.

Students indicated that when they experience injustice, in addition to such negative feelings as feeling sad, angry, irritated, weak, anxious, restricted, worthless, ashamed, grudge and hatred, they had such negative self-perceptions as doubting oneself, feeling under pressure, feeling that their efforts are in vain, feeling humiliated; and other negative feelings towards the process of education such as unwillingness to go to school which effect the process of education in a negative way. In addition, there were students who feel they were discriminated and believed that there was no justice. Students who witnessed injustice indicated that they felt sadness and anger etc. and one student indicated that $\mathrm{s} / \mathrm{he}$ empathized with the person who was the victim of injustice. On the other hand, a group of students mentioned the negativity of the conditions they live but stated that they got used to it and felt nothing. This is interpreted as they lost their belief in justice. Ripski \& Gregory (2009) indicate that unfair, hostile and unwelcome perception of the school climate were the predictors of lower students' engagement and academic achievement. Chory-Assad (2002), on the other hand, found that distributive and procedural justice are positively related to student motivation and effective learning, whilst they are negatively related to student aggression. Students who empathize with those who are victims of injustice reminds the "equity theory". In equity theory, when individuals perceive inequalities, rather than evaluating the situation from a narrow framework including such negative feelings as anger and guilt, they detail other options to re-establish equality (Scher \& Heise, 1993; cited in. Karaeminoğulları, 2006).

It was found that some of the students claim their rights when they experience injustice by complaining, talking about it or collecting evidences and the majority of the students preferred to stay silent and showing no reactions. Students prefer to stay silent as they feel helpless because they are afraid of being punished, they have to obey authority or because of their prior negative experiences. In other words, the problems in distributive justice effect students' behaviours of claiming their rights or standing against injustice.

Students efforts to claim their rights against injustice are appreciated. On the other hand, it is alarming that majority of the students prefer to stay silent because of fear, desperation and authority. If students do not show the behaviours of adolescence (such behaviours as questioning, standing against the rules) that is seen as a developmental problem and a danger in front of effective and conscious citizenship. Adolescents who do not use their rights, who accept the practices of the authorities without questioning and prefer to stay silent against the authority will more likely be passive citizens in their adulthood. Plato defines justice as one doing his/her full share of work during his/her lifetime in line with their competencies (cited in. Güriz, 1994). That the adults of the future are staying or preferring to stay silent against unfair practices creates question marks about how the concept of justice will be transferred to future generations.

The results of this study are supported with the results of Horan, Chory, \& Goodboy's (2010) study. In their study with university students, Horan, Chory, \& Goodboy (2010) found that distributive justice included grades, opportunities to improve grades, instructor affect, and punishment; whilst procedural justice included grading procedures, instructor error, class procedures etc. and interactional justice included insensitivity, rudeness, sexist/racist/prejudiced remarks, singling out students etc. The emotional reactions of the students change from anger to empathy and their behavioural reactions change from protesting to giving up.

The emotional and behavioural reactions of the students in this study against unfair experiences they had or witnessed are mainly negative. Erkan's (2013) findings are similar to the findings in this study. In his study, Erkan (2013) found that students mainly experience interactional justice issues and secondly, they experience distributive justice issues. The cases causing to interactional injustice as a result of violating the rules are given as issues related to respect, appropriateness and consistency. The ones related to distributive justice, on the other hand, are experienced when the rules relating to issues such as equity, equality and needs are violated. The participants indicated that they had negative feelings when they face an unfair situation and that they displayed generally passive and secondly aggressive behaviours.

When the process and results of the current study are evaluated, it is necessary to include some observations. The study group involved students studying at different types of high school. When students' answers are examined, it is seen that students cannot use Turkish language well and cannot express themselves good enough in writing. It is seen that the definition of justice does not differ depending on the type of high school but on the other hand, the situations that students consider as unfair change depending on the type of the high school. For example, in a high school where students with higher achievement study, students work against the clock for the university 
entrance exam and therefore, the right given to senior students to get their lunch first is seen as fair/unfair among the students. In schools with an average level of achievement, such issues as clothing, grading, favouring etc. cause to the reactions of the students. In schools, where students with low level of success study, evaluation of such situations as attending to school trips, social activities, arguments among the students or fights are effective in the definition of a situation as fair or unfair.

The basic relationship between people is ethical relationship. Ethical relationships and products of the people create the reality of the people and the society (Kuçuradi, 2011). Therefore, principals and teachers in educational institutions should be role-models for the students in terms of school rules (award-punishment, clothing), academic steps (exam, grading) and communication; this is an important factor to ensure that students believe in justice and internalize being fair.

The suggestions for future studies could be the examination of students' perception and opinions of justice based on school types and socio-economic status. Thus, a comparative study could be carried out by examining the opinions of the students studying in different regions in Turkey. In-depth analysis could be made through individual and group interviews and thus, opinions on justice perception could be identified.

This study has certain limitations. The fact that the study is carried out with Turkish high school students and is limited to only one city in Turkey is the limitation of the current study.

\section{References}

Akbaba, S. (2008). Ahlak ve gelişimi. In Y. Özbay \& S. Erkan (Eds.), Eğitim psikolojisi (pp. 165-203). Ankara: Pegem Akademi.

Anayasa.

(1982).

T.C.

Anayasa.

Retrieved

from http://www.anayasa.gov.tr/icsayfalar/mevzuat/1982anayasas\%C4\%B1.html

Bayer, F. (2008). Çocuk eğitim evleri ve ankara çocuk ve gençlik kapalı ceza infaz kurumunda kalmakta olan ergenlerin ahlaki yargı düzeylerinin incelenmesi. Yayınlanmamış Yüksek Lisans Tezi. Gazi Üniversitesi Eğitim Bilimleri Enstitüsü, Ankara.

Brockner, J. (2010). A contemporary look at organizational justice multiplying insult times injury. New York, USA: Routledge Taylor and Francis Group.

Çam, Z., Çavdar, D., Seydooğulları, S., \& Çok, F. (2012). Ahlak gelişimine klasik ve yeni kuramsal yaklaşımlar. Kuram ve Uygulamada Ĕgitim Bilimleri, 12(2), Özel ek, Bahar, 1211-1225.

Chory, R. M. (2007). Enhancing student perceptions of justice: the relationship between instructor credibility and classroom justice. Communication Education, 56-105. http://dx.doi.org/10.1080/03634520600994300

Chory-Assad, R. M. (2002). Classroom justice: Perceptions of justice as a predictor of student motivation, learning, and aggression. Communication $\quad$ Quarterly, 58-77. https://doi.org/10.1080/01463370209385646

Chory-Assad, R. M., \& Paulsel, M. L. (2004). Classroom justice: Student aggression and resistance as reactions to perceived injustice. Communication Education, 53(3), 253-273. https://doi.org/10.1080/0363452042000265189

Colquitt, J. A., Greenberg, J., \& Zapata-Phelan, C. P. (2005). What is organizational justice? A historical review. In J. Greenberg \& J. A. Colquitt (Eds.), The handbook of organizational justice (pp. 3-56). Mahwah, NJ: Erlbaum.

Cömert, M., Demirtaş, H., Üstüner, M., \& Özer, N. (2008). Lise öğretmenlerinin örgütsel adalet algıları [Organizational justice perceptions of high school teachers]. Eğitim Bilimleri ve Uygulama, 7(13), 3-22.

Corey, G. (2005). Psikolojik danışma, psikoterapi kuram ve uygulamalart. Ankara: Mentis

De Jong, D., \& Schalk, R. (2010). Extrinsic motives as moderators in the relationship between justice and work-related outcomes among temporary workers. Journal of Business and Psychology, 25(1), 175-189. https://doi.org/10.1007/s10869-009-9139-8

Erdoğan, M. (2008). Adalet ve eşitlik. Muhafazakar Düşünce, 4(15), 9-22.

Erkan, S. (2003). Okullarda tek tip ya da serbest kıyafet. Kuram ve Uygulamada Ĕ̆itim Yönetimi, 9(2), $268-279$.

Erkan, S. (2008). Gelişim psikolojisinde temel kavramlar. In Y. Özbay \& S. Erkan (Eds.), Eğitim Psikolojii (pp. 27-49). Ankara: Pegem. Akademi. 
Erkan, S. (2013). Perceptıons and experiences of justice amongst muslim post-secondary students in Canada (Unpublished doctoral dissertation). University of Saskatchewan, Canada.

Erkan, S., \& Walker, K., D. (2016). Fairness perceptions and experiences of muslim university students in Canada. International Education Studies, 9(7), 72-87. https://doi.org/10.5539/ies.v9n7p72

Erkuş, A. (2005). Bilimsel araştırma sarmalı. Ankara: Seçkin.

Ertürk, S. (1994). Eğitimde program geliştirme. Ankara: Meteksan Anonim Şirketi.

Gökler Danışman, I., \& Berberoğlu, E. (2016). Suça yönelen ergenlerde, çocukluk döneminde örseleyici yaşantılara maruz kalma düzeyi ile adil dünya inancı arasındaki ilişkinin incelenmesi. Anadolu Psikiyatri Dergisi, 17(2), 111-119.

Gündüz, T. (2000). Ergenlerde ahlak gelişimi ve cinsellik. Uludă̆ Üniversitesi İlahiyatFakültesi, 9(9). Retrieved from http://ucmaz.home.uludag.edu.tr/PDF/ilh/2000-9(9)/htmpdf/M-42.pdf

Güriz, A. (1994). Adalet kavramının belirsizliği. “Adalet Kavramı” isimli kitaptan ayrı basım. Ankara: Türkiye Felsefe Kurumu Yayını.

Harris, M. M., Lievens, F., \& Van Hoye, G. (2004). “I think they discriminated against Me:” Using prototype theory and organizational justice theory for understanding perceived discrimination in selection and promotion situations. International Journal of Selection and Assessment, 12(1/2), 54-65. https://doi.org/10.1111/j.0965-075X.2004.00263.x

Horan, S. M., Chory, R. M., \& Goodboy, A. K. (2010). Understanding students' classroom justice experiences and responses. Journal Communication Education, 59(4), $453-474$. https://doi.org/10.1080/03634523.2010.487282

İnsan Hakları Evrensel Beyannamesi. (1948). Retrieved from https://www.unicef.org/turkey/udhr/_gi17

Karaeminoğulları, A. (2006). Öğretim elemanlarının örgütsel adalet alglları ile sergiledikleri üretkenliğe aykırı davranışlar arasındaki ilişki ve bir araştırma (Yayınlanmamış yüksek lisans tezi). İstanbul Üniversitesi Sosyal Bilimler Enstitüsü, İstanbul.

Kayaoğlu, İ. (1986). İslamda adalet mefhumu. Ankara Üniversitesi İlahiyat Fakültesi Dergisi, 27(1), $201-206$. Retrieved from dergiler.ankara.edu.tr/dergiler/37/772/9836.pdf

Kepekçioğlu, E. S. (2015). Üniversite ögrencilerinin ögretim elemanlarının inanılırlı̆̆ı algısı ve sınıfta adalet algısı arasındaki ilişki. (Yayınlanmamış doktora tezi). Abant İzzet Baysal Üniversitesi, Eğitim Bilimleri Enstitüsü, Bolu.

Kuçuradi, İ. (2011). Etik. Türkiye Felsefe Kurumu. Ankara Özkan Matbaacılık.

Merriam, S. B. (2013). Nitel araştırma desen ve uygulama için bir rehber (Çev. Ed. S. Turan). Ankara: Nobel Yayınevi.

Miller, P. (2008). Gelişim psikolojisi kuramları (Yayına hazırlayan B. Onur). Ankara: İmge Kitabevi.

Nesbit, P. L., \& Burton, S. (2006). Student justice perceptions following assignment feedback. Assessment \& Evaluation in Higher Education, 31(6), 655-670.

Onur, B. (1979). Ahlak ĕgitiminin psikolojik temelleri. Retrieved from http://dergiler.ankara.edu.tr/dergiler/40/502/6006.pdf

Öztürk, O. (2008). Psikanaliz ve psikoterapi. Ankara: Nobel Tıp Kitabevi

Paulsel, M. L., \& Chory-Assad, R. M. (2005).Perceptions of instructor interactional justice as a predictor of student resistance. Communication Research Reports, 22(4), $283-291$. https://doi.org/10.1080/000368105000317565

Pehlivan, İ. (1998). Yönetsel mesleki ve örgütsel etik. Ankara: Pegem Yayınları.

Polat, S., \& Ceep, C. (2008). Ortaöğretim öğretmenlerinin örgütsel adalet, örgütsel güven, örgütsel vatandaşlık davranışlarına ilişkin algıları. Kuram ve Uygulamada Ĕ̆itim Yönetimi, 54, 307-331.

Polat, S., \& Kazak, E. (2014). Okul yöneticilerinin kayırmacı tutum ve davranışları ile öğretmenlerin örgütsel adalet algıları arasındaki ilişki. Kuram ve Uygulamada Eğitim Yönetimi [Educational Administration: Theory and Practice], 20(1), 71-92. 
Reyna, C., \& Weiner, B. (2001). Justice and utility in the classroom: an attributional analysis of the goals of teachers' punishment and intervention strategies. Journal of Educational Psychology, 93(2), 309-319. https://doi.org/10.1037/0022-0663.93.2.309

Ripski, M. B., \& Gregory, A. (2009). Unfair, unsafe, and unwelcome: do high school students' perceptions of injustice, hostility, and victimization in school predict engagement and achievement?. Journal of School Violence, 8(4), 355-375. https://doi.org/10.1080/15388220903132755

Şahin Fırat, N. (2010). Okul müdürü ve öğretmenlerin okul kültürü ile değer sistemlerine ilişkin algıları. Eğitim ve Bilim, 35(156), 71-83.

Schimdt, T. A. (2001). Assessing students' perceptions of instructor justice: An empirical investigation into significance of interactional, distributive and procedural justice in determination of justice (Unpublished doctoral dissertation). Saint Louis University. St.Louis, MO.

Steiner, D. D., Trahan, W. A., Haptonstahl, D. E., \& Fointiat, V. (2006). The justice of equity, equality, and need in reward distributions: a comparison of French and American respondents. Revue internationale de psychologie sociale, 1(19), 49-74.

TDK. (2017). Güncel Türkçe Sözlük. Türk Dil Kurumu. Retrieved from http://www.tdk.gov.tr/

Topakkaya, A. (2009). Aristoteles'te adalet kavramı. The Journal of International Social Research, 2(6), 628-633.

Töremen, F., \& Tan, Ç. (2010). Eğitim örgütlerinde adalet: kavramsal bir çözümleme. Dicle Üniversitesi Ziya Gökalp Eğitim Fakültesi Dergisi, 14, 58-70.

Van Den Bos, K., \& Lind, E. A. (2002). Uncertainty management by means of justice judgments. In M. P. Zanna (Ed.), Advances in experimental social psychology, 34, 1-60. San Diego, CA: Academic Press.

Wendorf, C. A., \& Alexander, S. (2005). The influence of individual and class level fairness- related perceptions on student satisfaction. Contemporary Educational Psychology, 30(2), 190-206. https://doi.org/10.1016/j.cedpsych.2004.07.003

Yeşilyaprak, B. (2012). 21. yy. Eğitimde rehberlik hizmetleri. Gelişimsel yaklaşım. Ankara: Nobel Yayınevi.

Yıldırım, A., \& Şimşek, H. (2011). Sosyal bilimlerde nitel araştırma yöntemleri (8. baskı). Ankara: Seçkin Yayıncilık.

\section{Copyrights}

Copyright for this article is retained by the author(s), with first publication rights granted to the journal.

This is an open-access article distributed under the terms and conditions of the Creative Commons Attribution license (http://creativecommons.org/licenses/by/4.0/). 